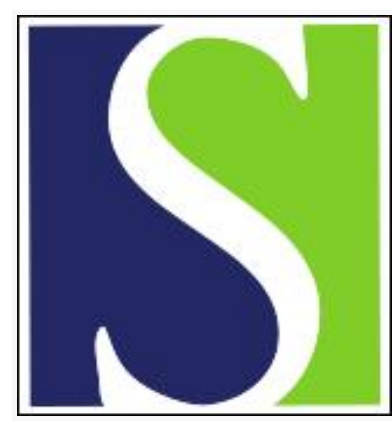

Scand J Work Environ Health 1984;10(5):299-303

https://doi.org/10.5271/sjweh.2325

Issue date: Oct 1984

An evaluation of reports of dioxin exposure and soft tissue sarcoma pathology among chemical workers in the United States.

by Fingerhut MA, Halperin WE, Honchar PA, Smith AB, Groth DH, Russell WO

This article in PubMed: www.ncbi.nlm.nih.gov/pubmed/6523094

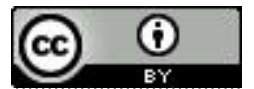




\title{
An evaluation of reports of dioxin exposure and soft tissue sarcoma pathology among chemical workers in the United States
}

\author{
by Marilyn A Fingerhut, PhD, ${ }^{1}$ William E Halperin, MD, ${ }^{1}$ Patricia A Honchar, $\mathrm{PhD},{ }^{1}$ \\ Alexander B Smith, MD, ${ }^{1}$ David H Groth, MD, ${ }^{1}$ William O Russell, $\mathrm{MD}^{2}$
}

\begin{abstract}
FINGERHUT MA, HALPERIN WE, HONCHAR PA, SMITH AB, GROTH DH, RUSSELL WO. An evaluation of reports of dioxin exposure and soft tissue sarcoma pathology among chemical workers in the United States. Scand J Work Environ Health 10 (1984) 299-303. A review of employment records and tissue specimens of seven workers, reported previously as having occupational dioxin exposure and soft tissue sarcomas, confirms that four workers had employment of 2 to 19 years in the production of $2,4,5$-trichlorophenoxyacetic acid $(2,4,5-\mathrm{T})$ or trichlorophenol, products contaminated with $2,3,7,8$-tetrachlorodibenzodioxin, the most toxic dioxin isomer. Of these individuals, two have confirmed soft tissue sarcomas. In addition three individuals who worked for companies which made 2,4,5-T also have confirmed soft tissue sarcomas. Their employment records do not show specific assignment to 2,4,5-T or trichlorophenol departments; however, one individual worked for $10 \mathrm{~d}$ in the production of pentachlorophenol, which is contaminated with different isomers of dioxin. Methodological problems are discussed which must be addressed in the epidemiologic evaluation of the outcome of soft tissue sarcoma.
\end{abstract}

Key terms: occupational exposure, phenoxy herbicides, 2,3,7,8-tetrachlorodibenzodioxin, 2,4,5-trichlorophenoxyacetic acid.

Data from two Swedish studies $(3,6)$ and a review of four studies of dioxin-exposed workers in the United States (US) (7) have suggested that occupational exposure to dioxin-contaminated products is associated with an increased risk of soft tissue sarcoma (STS). Soft tissue sarcomas are malignant neoplasms of diverse histological subtypes, which arise throughout the body from mesenchymal supporting tissue other than bone (14). The principal types of histopathological subtypes are listed in table 1 .

Dioxins occur as unintended contaminants during the chemical manufacture of chlorinated phenoxy acetic acids and chlorinated phenols. Industrial workers who produce these products, and herbicide applicators who spray them, have been potentially exposed both to the products and to their dioxin contaminants. In 1977 several cases of soft tissue sarcoma were reported among Swedish lumberjacks who had prior exposure to phenoxy acid herbicides (4). This clinical observation led researchers in Sweden to conduct two separate case-referent studies (3, 6). Both studies found that persons with occupa-

\footnotetext{
1 National Institute for Occupational Safety and Health, Cincinnati, Ohio, United States.

2 North Ridge General Hospital and North Ridge Cancer Foundation, Fort Lauderdale, Florida, United States.
}

Reprint requests to: Dr MA Fingerhut, National Institute for Occupational Safety and Health, Robert A Taft Laboratories, 4676 Columbia Parkway, Cinncinnati, $\mathrm{OH} 45226$, USA. tional exposure to phenoxy acid herbicides or chlorophenols had shown an approximately fivefold increase in the risk of developing a soft tissue sarcoma.

At about the same time four mortality studies (2, $10,16,17)$ of workers exposed to the herbicide 2,4,5-trichlorophenoxyacetic acid $(2,4,5-\mathrm{T})$ or its chemical precursor, trichlorophenol, were conducted in US manufacturing plants. The dioxin isomer contaminating these products is the most toxic form, 2,3,7,8-tetrachlorodibenzodioxin (2,3,7,8-TCDD). None of the four studies found any statistically significant excess in total mortality or death from cancer attributed to dioxin exposure by the authors. However each cohort was small and had insufficient statistical power for an adequate evaluation of rare causes of death.

Table 1. Histopathological varieties of sarcoma of soft tissue $^{a}$

\begin{tabular}{lc}
\hline Histopathological variety & $\begin{array}{c}\text { Percentage of } \\
\text { total cases }\end{array}$ \\
\hline Rhabdomyosarcoma & 19.2 \\
Fibrosarcoma & 19.0 \\
Liposarcoma & 18.2 \\
Malignant fibrohistiocytoma & 10.5 \\
Sarcoma of soft tissue, type unspecified & 10.0 \\
Synovial sarcoma & 6.9 \\
Leiomyosarcoma & 6.5 \\
Malignant schwannoma & 4.9 \\
Angiosarcoma & 2.7 \\
Other types & 1.9 \\
\hline
\end{tabular}

a Data from a study of 1215 cases described by Russell et al (12). 
In a review of these studies (7) it was noted that three $(2.9 \%)$ of the total 105 deaths in the four merged cohorts had been attributed in the reports to soft tissue sarcoma when, based on national statistics, only $0.07 \%$ of the deaths was expected to be due to this cause. Subsequent to the review, a fourth person in one of the cohorts was reported as having a soft tissue sarcoma (1); he was alive at the time of the report but is now deceased. In additional responses to this review (7) three individuals were noted by their physicians $(8,9)$ to have soft tissue sarcoma and to have worked at chemical manufacturing sites which made 2,4,5-T and chlorophenols. Table 2 presents a chronology of these reports of US workers ex-

Table 2. A chronology of reports of chemical workers with dioxin exposure in the United States.

\begin{tabular}{|c|c|c|c|c|c|}
\hline Type of report & Source of exposure ${ }^{a}$ & Size of cohort & $\begin{array}{l}\text { Number of } \\
\text { deaths }\end{array}$ & $\begin{array}{c}\text { Number of } \\
\text { cases of soft } \\
\text { tissue sarcoma }\end{array}$ & Reference \\
\hline Cohort mortality study & TCP & 61 & 4 & 1 & Cook et al (2) \\
\hline Cohort mortality study & 2,4,5-T, TCP & 204 & 11 & 0 & Ott et al (10) \\
\hline Cohort mortality study & $\mathrm{TCP}$ & 121 & 32 & $t$ & Zack \& Suskind (17) \\
\hline Proportional mortality study & TCP, 2,4,5-T & $-b$ & 58 & 1 & Zack \& Gaffey (16) \\
\hline Review of the American studies & TCP, 2,4,5-T & $一$ & $105^{c}$ & $3^{c}$ & Honchar \& Halperin (7) \\
\hline $\begin{array}{l}\text { Addendum to cohort of } 61 \\
\text { in cohort mortality study of } \\
\text { Cook et al (2) }\end{array}$ & TCP & - & - & $1^{d}$ & Cook (1) \\
\hline Case report & $\begin{array}{l}\text { Possibly TCP } \\
\text { or } 2,4,5-\mathrm{T}\end{array}$ & - & 1 & 1 & Moses \& Selikoff (9) \\
\hline Case report & $\begin{array}{l}\text { Possibly chloro- } \\
\text { phenols or } 2,4,5-\mathrm{T}\end{array}$ & - & 1 & 2 & Johnson et al (8) \\
\hline
\end{tabular}

a $\mathrm{TCP}=$ trichlorophenol; 2,4,5-T $=2,4,5$-trichlorophenoxyacetic acid.

b The authors did not state the number of live workers.

c Honchar summed the number of deaths and cases of soft tissue sarcoma in the four American studies.

d This individual belongs to the cohort of 61 in the cohort mortality study of Cook et al (2); he died in 1983 .

Table 3. Diagnoses from death certificates, original pathology reports, and two pathological reviews of tissue specimens. ${ }^{a}$

\begin{tabular}{|c|c|c|c|c|}
\hline $\begin{array}{l}\text { Case } \\
\text { number }\end{array}$ & $\begin{array}{l}\text { Death } \\
\text { certificate }\end{array}$ & $\begin{array}{l}\text { Original } \\
\text { pathology reports }\end{array}$ & Review 1 & Review 2 \\
\hline 1 & $\begin{array}{l}\text { Malignant fibrous } \\
\text { histiocytoma }\end{array}$ & $\begin{array}{l}\text { Malignant fibrous } \\
\text { histiocytoma }\end{array}$ & $\begin{array}{l}\text { Malignant fibrous } \\
\text { histiocytoma }\end{array}$ & $\begin{array}{l}\text { Malignant fibrous } \\
\text { histiocytoma }\end{array}$ \\
\hline 2 & Liposarcoma & Liposarcoma & $\begin{array}{l}\text { (Carcinoma, poorly } \\
\text { differentiated) }\end{array}$ & $\begin{array}{l}\text { (Carcinoma, poorly } \\
\text { differentiated) }\end{array}$ \\
\hline 3 & Fibrosarcoma & Fibrosarcoma & $\begin{array}{l}\text { (Clear cell carcinoma } \\
\text { with spindling, renal) }\end{array}$ & $\begin{array}{l}\text { (Spindle cell renal } \\
\text { carcinoma) }\end{array}$ \\
\hline 4 & $\begin{array}{l}\text { Malignant fibrous } \\
\text { histiocytoma }\end{array}$ & $\begin{array}{l}\text { Malignant fibrous } \\
\text { histiocytoma }\end{array}$ & $\begin{array}{l}\text { Malignant fibrous } \\
\text { histiocytoma }\end{array}$ & $\begin{array}{l}\text { Malignant } \\
\text { schwannoma }\end{array}$ \\
\hline 5 & (Carcinomatosis) & $\begin{array}{l}\text { Myxoid neurogenic } \\
\text { sarcoma }\end{array}$ & Leiomyosarcoma & $\begin{array}{l}\text { Malignant fibrous } \\
\text { histiocytoma }\end{array}$ \\
\hline 6 & $\begin{array}{l}\text { (Metastatic } \\
\text { mesothelioma) }\end{array}$ & Fibrosarcoma & $\begin{array}{l}\text { Malignant } \\
\text { schwannoma }\end{array}$ & $\begin{array}{l}\text { Malignant } \\
\text { schwannoma }\end{array}$ \\
\hline 7 & Alive & $\begin{array}{l}\text { Myxoid } \\
\text { liposarcoma }\end{array}$ & $\begin{array}{l}\text { Myxoid } \\
\text { liposarcoma }\end{array}$ & $\begin{array}{l}\text { Myxoid } \\
\text { liposarcoma }\end{array}$ \\
\hline
\end{tabular}

a Review 1 was conducted at the Armed Forces Institute of Pathology, Washington, DC. Review 2 was conducted by one of the authors, William O Russell, MD. All terms refer to histological subtypes of soft tissue sarcoma with the exception of those presented in parentheses.

Table 4. Chloracne and latency for cancer among dioxin-exposed workers.

\begin{tabular}{|c|c|c|c|c|c|}
\hline $\begin{array}{l}\text { Case } \\
\text { number }\end{array}$ & $\begin{array}{l}\text { First recorded } \\
\text { exposure }\end{array}$ & $\begin{array}{l}\text { Onset of soft } \\
\text { tissue sarcoma }\end{array}$ & Age at onset & $\begin{array}{l}\text { Latency }^{a} \\
\text { (years) }^{\text {a }}\end{array}$ & $\begin{array}{l}\text { Diagnosed } \\
\text { chloracne }\end{array}$ \\
\hline $\begin{array}{l}1 \\
2 \\
3 \\
4 \\
5 \\
6 \\
7\end{array}$ & $\begin{array}{c}1949 \\
1950 \\
1964 \\
1951 \\
\text { NA b } \\
\text { NA } \\
1951\end{array}$ & $\begin{array}{l}1978 \\
1972 \\
1973 \\
1979 \\
1980 \\
1980 \\
1980\end{array}$ & $\begin{array}{l}58 \\
49 \\
52 \\
58 \\
57 \\
33 \\
53\end{array}$ & $\begin{array}{r}29 \\
21 \\
9 \\
28 \\
\text { NA } \\
\text { NA } \\
29\end{array}$ & $\begin{array}{l}\text { Yes } \\
\text { Yes } \\
\text { No } \\
\text { Yes } \\
\text { No } \\
\text { No } \\
\text { No }\end{array}$ \\
\hline
\end{tabular}

a Exposure is defined as employment in a 2,4,5-trichlorophenoxyacetic acid, trichlorophenol, or pentachlorophenol department. Latency is the time from first employment to onset of tumor.

b NA = not applicable. Worker had no record of employment in 2,4,5-trichlorophenoxyacetic acid, trichlorophenol, or pentachlorophenol department. 
posed to dioxin.

As researchers at the National Institute for Occupational Safety and Health (NIOSH), we were interested in the seven individuals noted in these reports in the US literature because, in 1979, we had initiated a cohort mortality study (5) of all US production workers potentially exposed to dioxin during the production of trichlorophenol, 2,4,5-T, and pentachlorophenol (PCP). Trichlorophenol and 2,4,5-T are contaminated with the most toxic dioxin isomer, $2,3,7,8-T C D D$, and pentachlorophenol contains hexa-, hepta- and octachlorinated dioxins. Since soft tissue sarcoma had been associated with exposure to these products in Sweden $(3,6)$, we decided to obtain medical and exposure data for the seven US workers, in order to evaluate their exposure to dioxin and to ascertain whether there was any histological commonality among their soft tissue sarcomas. Our intention was to characterize the soft tissue sarcoma pathology in preparation for the evaluation of this outcome in the NIOSH cohort mortality study.

\section{Subjects and methods}

We obtained detailed employment records, medical and pathological reports, tissue specimens, and death certificates for the seven individuals. We evaluated the potential for exposure to 2,3,7,8-TCDD and hexa-, hepta-, and octachlorinated dioxins by a careful examination of the employment records. By our criterion, an individual was considered "exposed" if he had a company record of assignment to a department producing trichlorophenol, 2,4,5-T, or pentachlorophenol. This stringent definition of exposure was chosen because it provided an objective method for determining exposure and because it was the criterion we were using in the NIOSH cohort study. In order to evaluate the soft tissue sarcomas among the individuals, we obtained death certificates for the six deceased persons and medical records from hospitals and employers for all the individuals. In addition we obtained tissue specimens for all seven persons. The tissue specimens were examined in two independent reviews by pathologists with expertise in the area of soft tissue sarcomas.

\section{Results}

The four individuals, whose exposure and cause of death were originally reported in cohort studies conducted by the companies for which they worked ( 1 , $2,16,17)$, are referred to as cases 1 to 4 . The three individuals originally described by their physicians as case reports $(8,9)$ are identified as cases 5 to 7 .

Table 3 compares the original pathological diagnoses for the seven individuals with the diagnoses selected in two independent reviews by expert soft tissue sarcoma pathologists who examined all the tissue specimens. Although all seven individuals had re- ceived diagnoses of soft tissue sarcoma by their original pathologists, only five of the cases were diagnosed as soft tissue sarcoma by each of the two reviewers. Both reviewers independently diagnosed the tissue specimens from cases 2 and 3 as carcinomas.

Differences in the diagnoses of histological subtypes of soft tissue sarcoma can also be observed in table 3. Although the original pathologists and the two reviewers all agreed that five individuals had soft tissue sarcomas, they agreed on the histological subtype for only two individuals, cases 1 and 7 . Even the two expert reviewers disagreed on subtype diagnoses for cases 4 and 5 .

Table 3 also compares the information recorded on the death certificates with the diagnoses made by the original pathologists and by our independent reviewing pathologists. Of the six deceased cases, only four (cases 1 to 4) had notations of soft tissue sarcoma on their death certificates. By contrast, all six deceased individuals, and also case 7 , had hospital diagnoses of soft tissue sarcoma.

Table 4 summarizes the medical information we obtained from company and hospital medical records. Cases 1, 2, and 4 had records of diagnosed chloracne, and case 3 had dermatitis of the face and neck while assigned to the trichlorophenol building during a period when 49 trichlorophenol workers developed chloracne (2). In considering whether the chemical exposure might be associated with the soft tissue sarcomas, we evaluated whether adequate time (latency) had elapsed between the exposure and the onset of the cancer. We chose the first day of assignment to a 2,4,5-T, trichlorophenol, or pentachlorophenol department as the date of the first recorded exposure. Since our strict definition of exposure required records of assignment to 2,4,5-T, trichlorophenol, or pentachlorophenol departments, we did not calculate latency for cases 5 or 6 .

The employment records (see table 5) confirmed the original reports that cases 1,2 , and 4 were production workers (chemical operators) assigned to the trichlorophenol or 2,4,5-T departments. Case 3 was a maintenance worker identified by the company as assigned to a building where trichlorophenol was produced. Case 5 worked in production, clerical work, truck driving, and maintenance jobs during his 32 years in a chemical manufacturing site which produced trichlorophenol, 2,4,5-T, and many other chemicals, but he had no record of specific assignment to a trichlorophenol or 2,4,5-T department. Case 6 worked two and a half years in a plant which made $2,4,5-\mathrm{T}$. He was a production worker but had no record of assignment to the 2,4,5-T area. Case 7 was the father of case 6 and was a production and maintenance worker at the same facility for 29 years. His work history showed no record of assignment to the 2,4,5-T area; however, he worked for $11 \mathrm{~d}$ following his hiring in 1951 in a pentachlorophenol area. 

Table 5. Exposure data obtained from employment records. (TCP $=$ trichlorophenol; $P C P=$ pentachlorophenol; 2,4,5-T $=$
2,4,5-trichlorophenoxyacetic acid)

\begin{tabular}{|c|c|c|c|c|c|}
\hline $\begin{array}{l}\text { Case } \\
\text { number }\end{array}$ & Facility & Years of employment & Job title ${ }^{a}$ & Exposure ${ }^{a}$ & $\begin{array}{c}\text { Duration of } \\
\text { exposure }\end{array}$ \\
\hline $\begin{array}{l}1 \\
2 \\
3 \\
4 \\
5\end{array}$ & $\begin{array}{l}A \\
A \\
B \\
B \\
A\end{array}$ & $\begin{array}{l}1946-1978 \\
1946-1972 \\
1950-1975 \\
1951-1982 \\
1943-1975\end{array}$ & $\begin{array}{l}\text { TCP operator } \\
2,4,5-T \text { operator } \\
\text { Maintenance } \\
\text { TCP operator } \\
\text { Clerical, maintenance, truck } \\
\text { driver, production worker }\end{array}$ & $\begin{array}{l}\text { TCP } \\
2,4,5-T \\
\text { TCP } \\
\text { TCP } \\
-\end{array}$ & $\begin{array}{l}1.9 \text { years } \\
2.0 \text { years } \\
3.5 \text { years } \\
19.0 \text { years } \\
-\end{array}$ \\
\hline $\begin{array}{l}6 \\
7\end{array}$ & $\begin{array}{l}\mathrm{C} \\
\mathrm{C}\end{array}$ & $\begin{array}{l}1978-1980 \\
1951-1980\end{array}$ & $\begin{array}{l}\text { Production worker } \\
\text { Production worker }\end{array}$ & $\overline{P C P}$ & $\overline{11}$ days \\
\hline
\end{tabular}
a Exposure is defined as employment in a 2,4,5-trichlorophenoxyacetic acid, trichlorophenol, or pentachlorophenol depart-
ment.

\section{Discussion}

\section{Association between dioxin exposure and soft tissue sarcoma}

In this article we present an evaluation of the causes of death based upon pathological review of tissue specimens of seven US workers reported to have dioxin exposure and soft tissue sarcoma. It is our opinion that the question of association of dioxin exposure and soft tissue sarcoma is confined to cases 1 to 4 because they are members of defined cohorts which, together, contain a total of fewer than 1000 workers (see table 2). All four individuals were exposed to $2,3,7,8-T C D D$, and two have pathologically confirmed soft tissue sarcoma. Does this constitute an excess? Unfortunately we are unable to justify a definitive conclusion because we know of no valid comparison group. There are no population-based rates for soft tissue sarcoma which are generated following pathological review of tissue specimens. Our finding does not contradict the Swedish conclusions $(3,6)$, but neither can it be used to confirm their conclusions. It is our view that a definitive conclusion may be reached when the epidemiologic studies are completed which are underway in several countries.

\section{Difficulties in verifying exposure}

Cases 5,6, and 7, originally described as case reports of pathologically confirmed soft tissue sarcoma, contribute little information to the question of excess deaths because the individuals do not belong to any cohort whose total number is known. However the evaluation of the exposure of these three individuals illustrates some difficulties encountered in attempting to verify the exposure of chemical workers. In our review of their employment records we did not find that they had been assigned to $2,4,5$-T or trichlorophenol departments; but case 7 worked briefly in the production of pentachlorophenol, which is contaminated with hexa-, hepta-, and octachlorinated isomers of dioxin. Using our rigorous criterion that exposure be documented by a record of assignment to a $2,4,5-\mathrm{T}$ or trichlorophenol or pentachlorophenol department, we cannot conclude that case 5 or 6 was exposed to dioxin. However absence of such documentation does not eliminate the possibility that they actually may have been exposed to such products during their daily activities. Work history records of production workers usually list their regular assignments, but they may not show temporary changes. Maintenance workers such as case 5 often work throughout an entire facility and never have recorded assignments in specific departments.

\section{Inadequacy of death certificate data}

We have identified two problems associated with the use of death certificate data for the evaluation of soft tissue sarcoma. First the data may result either in the underascertainment or in the overascertainment of cases of soft tissue sarcoma. We observed that, of six deceased individuals who had hospital diagnoses of soft tissue sarcoma, only four had soft tissue sarcoma noted on their death certificates. A similar finding of underascertainment was noted in a study of the accuracy of death certificates conducted by Percy et al, in 1981, who reviewed almost 50000 hospital diagnoses and death certificates (11). We also found that all four death certificates with notations of soft tissue sarcoma (cases 1 to 4) belonged to persons who in fact had hospital diagnoses of soft tissue sarcoma. In contrast Percy et al (11) found that, of death certificates with a notation of soft tissue sarcoma, only $56 \%$ were supported by hospital records with the same diagnosis. That finding suggests that using death certificates as the primary source of cases without confirming hospital or pathological information may also lead to an overascertainment of cases.

The second problem is that only about $60 \%$ of all soft tissue sarcomas can be identified from death certificate data. Cause of death is coded from death certificates by nosologists according to the rules of the International Classification of Disease (ICD) system (15), which is organized by anatomic sites. According to these rules, soft tissue sarcomas of the supporting tissue of the body which are not specified as arising in organs are coded in the category ICD 171, malignant neoplasms of the soft and connective tissues. Therefore sarcomas that develop in the parenchymatous organs such as the uterus or stomach are coded 
into the ICD categories for the organ site. A document prepared by L Hardell for the US Environmental Protection Agency indicated that approximately $40 \%$ of the soft tissue sarcoma cases selected histologically for the Swedish studies are coded in ICD categories other than ICD 171.

\section{Variation in the selection of cases of soft tissue sarcoma in epidemiologic studies}

For the early Swedish studies $(3,6)$ cases were selected by their histopathological characteristics. A current case-referent study in New Zealand (13) includes only soft tissue sarcoma cases coded as ICD 171. Such differences in design must be recognized when results are evaluated.

\section{Difficulties in the pathological diagnosis of soft tissue sarcoma and its histological subtypes}

As illustrated by cases 2 and 3 in table 3, difficulties are encountered in the pathological diagnosis of soft tissue sarcomas. These findings suggest that review of tissue specimens by pathologists with expertise in diagnosing soft tissue sarcomas may be necessary for epidemiologic studies. A difficult problem arises for cohort mortality studies because there is no comparison group for cases ascertained through tissue review by expert pathologists.

The diagnosis of the histological subtypes of soft tissue sarcoma also presents difficulties, particularly when only a limited amount of tissue is available for review. As illustrated in table 3 , cases 4 and 5 received different subtype choices from pathologists with expertise in diagnosing soft tissue sarcoma. Therefore we recommend that epidemiologic studies continue to focus on the outcome of the category of soft tissue sarcoma and assess the distribution of histological subtypes only cautiously and with a recognition of the limitations involved.

\section{Conclusion}

Our article points out the complexities involved in evaluating the outcome of soft tissue sarcoma. It emphasizes the need for carefully designed large epidemiologic studies to assess adequately the possibility of an association between soft tissue sarcoma and exposure to dioxin contaminated products. We have noted several methodological problems which must be addressed by these studies. We suggest that pathological examination of tissue specimens by soft tissue sarcoma experts may be necessary to identify cases of soft tissue sarcoma accurately and that histological subtypes should be assessed with caution. We have shown that the use of the death certificate alone may lead to overascertainment or underascertainment of cases of soft tissue sarcoma. It is our view that a definitive conclusion cannot be drawn to confirm or refute the association first suggested in the Swedish studies until the epidemiologic studies have been completed which are currently underway in several countries.

\section{Acknowledgments}

We thank FM Enzinger, MD, and SM Weiss, MD, of the Armed Forces Institute of Pathology, Washington, DC, for reviewing the pathological specimens and offering their expert opinions. We also thank Ms K Hollowell, Ms R McGrath, Ms S Morgan, and Ms F Guerra for their assistance with the preparation of this report.

\section{References}

1. Cook RR. Dioxin, chloracne and soft tissue sarcoma. Lancet 1 (1981) 618-619.

2. Cook RR, Townsend JC, Ott MG. Mortality experience of employees exposed to 2,3,7,8-tetrachlorodibenzodioxin (TCDD). J Occup Med 22 (1980) 530532.

3. Eriksson M, Berg N, Hardell L, Moller T, Axelson O. Soft tissue sarcomas and exposure to chemical substances, a case-referent study. Br J Ind Med 38 (1981) $27-33$.

4. Hardell L. Soft tissue sarcomas and exposure to phenoxyacetic acids - Clinical observation. Lakartidningen 74 (1977) 2753-2754.

5. Fingerhut MA, Marlow DA, Halperin WE, Honchar PA. The NIOSH dioxin registry. In: Lowrance W, ed. Public health risks of dioxin. The Rockefeller University, New York, NY 1984.

6. Hardell L, Sandström A. Case-control study: Softtissue sarcomas and exposure to phenoxyacetic acids or chlorophenols. Br J Cancer 39 (1979) 711-717.

7. Honchar PA, Halperin WE. 2,4,5-Trichlorophenol and soft tissue sarcoma. Lancet 1 (1981) 268-269.

8. Johnson FE, Kugler NA, Brown SM. Soft tissue sarcomas and chlorinated phenols. Lancet 1 (1981) 40.

9. Moses M, Selikoff IJ. Soft tissue sarcomas, phenoxy herbicides and chlorinated phenols. Lancet 1 (1981) 1370.

10. Ott MG, Holder BB, Olson RD. A mortality analysis of employees engaged in the manufacture of 2,4,5-trichlorophenoxyacetic acid. J Occup Med 22 (1980) 47-50.

11. Percy C, Stanek E, Gloeckler L. Accuracy of cancer death certificates and its effect on cancer mortality statistics. Am J Publ Health 71 (1981) 242-250.

12. Russell WO, Cohen J, Enzinger F, Hajdu S, Heise H, Martin RG, Meissner W, Miller WT, Schmitz RL, Suit HD. A clinical and pathological staging system for soft tissue sarcomas. Cancer 40 (1977) 1562-1570.

13. Smith AH, Fisher DO, Pearce N, Teague CA. Do agricultural chemicals cause soft tissue sarcoma? Initial findings of a case control study in New Zealand. Community Health Stud 6 (1982) 114-119.

14. Suit HD. Sarcoma of soft tissue. CA-A Cancer J Clin 28 (1978) 284-295.

15. World Health Organization. Manual of the international statistical classification of diseases, injuries and causes of death. Ninth Revision. Geneva 1977.

16. Zack JA, Gaffey WR. A mortality study of workers employed at the Monsanto Company plant in Nitro, West Virginia. Environ Sci Res 26 (1983) 575-591.

17. Zack JA, Suskind RS. The mortality experience of workers exposed to tetrachlorodibenzodioxin in a trichlorophenol process. J Occup Med 22 (1980) $11-14$.

Received for publication: 3 May 1984 